\title{
Key Issues in Forging Credible Corporate Social Responsibility Partnerships
}

\author{
Khalid Nasir \\ Shadab Fariduddin
}

\begin{abstract}
Corporate Social Responsibility (CSR) is a burgeoning practice where businesses in Pakistan are becoming increasingly interested, active and innovative. Spread of CSR has created necessity for corporate organizations to enter into purposeful partnerships with the development sector organizations. These partnerships enable the corporate sector to become an active social investor while expanding development sector's reach and impact. However, there is a disconnect in forming partnerships owing to lack of awareness and misconception on both sides about each other's performance and intent to carry out triumphant CSR projects. This research highlights the key issues that inhibit the credible CSR partnerships. The study concludes that CSR-centricity is gaining traction and the lack of understanding about each others' motivations does inhibit formation of credible CSR partnerships owing to four top key issues and a dissimilar set of intentions to perform CSR. The study also highlights corporate philanthropy as the top CSR initiative and environment conservation, education and health care as top causes for CSR.
\end{abstract}

Keywords: Corporate Social Responsibility, Business-NGO Collaboration, CSR Partnerships, CSR in Pakistan, Effective CSR Partnership, Corporate Responsibility.

\section{Introduction}

\subsection{Background of the Study}

Universally in general and in the newer consumer-based economy of Pakistan in particular, Corporate Social Responsibility (CSR) has become a boardroom agenda. It has altered the traditional purview of corporate philanthropy. This paradigm shift has cultivated the concept of 'Triple Bottom-Line' approach that relates to the well being of People, care for the Planet and increased Profits. With this expanded spectrum of deliverables, CSR has grown to be multidimensional in its approach, widespread in its impact and strategic in its nature.

Globally CSR has become a qualifying indicator for the corporate entity to being a good 'corporate citizen'. IBM Global CEO study of 2008 rated CSR among the top five traits needed for the success of future enterprise. A study in 1999 conducted by Environics International Ltd surveyed 25,000 citizens in 23 countries highlighted that $60 \%$ of respondents form an impression of a company based on its CSR actions (Kotler, 2005).

Khalid Nasir is an MS student at SZABIST, Karachi, kaynasir@hotmail.com

Shadab Fariduddin is lead consultant at Four Corners Group, shadab@fourcg.com

Journal of Independent Studies and Research - MSSE

Volume $8 \quad$ Number 1

January 2010 171 
With this increasing significance of CSR, a development sector infrastructure has taken shape to support the corporate organizations by having enduring partnerships for productive CSR interventions. Catching on this global trend, the CSR interventions by the corporate sector of Pakistan has increased manifolds. A survey of 546 public listed companies (Pakistan Center of Philanthropy, 2006) revealed total donations increased 10 times from Rs. 228 million in 2000 to Rs. 2.3 billion in 2006 and corporate-giving increased from $54 \%$ in 2005 to $60 \%$ in 2006 .

With the increase in CSR activities in Pakistan, the issue of having credible CSR partnership between corporate and developmental sector has surfaced. The challenge of finding a worthy

partner to have a successful CSR experience looms at large and organizations are keen to find out the key issues that restrain development of synergistic partnerships to carry out sustainable joint CSR interventions. As no explicit statement about the key issues or empirical research on CSR is available in Pakistan, the findings of this research will serve as an attempt to explore these key issues.

\subsection{Research Problem}

To explore the key issues and factors in forging credible CSR partnerships between the corporate and development sectors.

\subsection{Research Objectives}

The prime objective of this research is to explore the key issues and factors that inhibit the corporate and development sector organizations to form credible CSR partnerships. The study also inquires into the driving factors to perform CSR and its emerging trends.

\subsection{Significance of the Study}

As CSR is a recent and nascent phenomenon in Pakistan, this study is an attempt to address to the inadequacy of existing body of codified knowledge on the subject. The findings of this research will be of immense value to the corporate organization, especially for its CSR function as it would clear the mist that exists in creating partnerships for CSR interventions. The study would equally benefit the development sector in addressing the key partnership issues and to pursue the corporate entity to consider their organization as a reliable CSR partner. The findings will also be helpful to the academia for the teaching discourse.

\subsection{Research Methodology}

Both primary and secondary sources were consulted during this research. The process of research tool development involved the following steps:

(a) Literature review from available local and foreign published scholastic work. 
However, insufficiency of local literature on CSR compelled us to draw upon experts' knowledge for development of a cognitive framework

(b) Expert interviews were taken where they were asked to reflect upon their experience and identify factors of credible CSR partnerships. They were also asked to rank order them. The experts comprised from both business and social organizations

(c) A prototype of the cognitive framework was then designed based on the two above and was pre-tested in a smaller sample for validity.

A list of key issues and factors was hence developed through literature review and surveying the local industry. The final list of 11 key issues was converted into a cognitive framework and a corresponding questionnaire, among other questions, was developed and circulated to 60 corporate and development sector organizations using convenient sampling method. The total response spread of 34 organizations comprises 18 for-profit and 16 not-for-profit organizations in Karachi. To test whether the key issues impact the CSR partnerships, following null hypothesis was assumed and tested using Liner Regression model:

$\mathrm{H}_{0}$ - Lack of understanding about each other's motivations and intentions does inhibit formation of credible CSR partnerships

$\mathrm{H}_{1}$ - Lack of understanding about each other's motivations and intentions does not inhibit formation of credible CSR partnerships

\section{Literature Review}

As the concept and practice of Corporate Social Responsibility (CSR) continues to evolve, so does its definition. Even the word 'CSR' has matured into a shortened and universally accepted more meaningful version of Corporate Responsibility or CR. Kotler (2005) refers to CSR as "a commitment to improve community well-being through discretionary business practices and contributions of corporate resources" which indicates that CSR is a voluntary commitment. It is not a 'must have' but a 'good to have' choice. The World Business Council for Sustainable Development (WBSCD) defines CSR as "the continuing commitment by business to behave ethically and contribute to economic development while improving the quality of life of the workforce and their families as well as of the local community and society at large" (MacDonald, 2006). Fariduddin (2008) mentioned that CSR is done for C.S.R.: Capacity, Structure, and Relevance where Capacity is the organization's capability to handle the intellectual input that comes with CSR; Structure of organization that supports the CSR strategy while having Relevance of practicing CSR as per organizational values and market positioning. Kotler (2005) mentioned that CSR makes an organization 'looks good' to potential customers and investors; 'feels good' to current stakeholders and also that CSR 'does good' to an organization's bottom line, brand as well as for the community. CSR could be expressed through six initiatives that include cause promotions, cause-related marketing, corporate social marketing, employee volunteering, corporate philanthropy and socially responsible 
business practices (Kotler, 2005). Kotler's concept also connects with the 'triple bottom line' approach of CSR that relates to well- being of people and planet while ensuring profits as an outcome of a CSR intervention.

\subsection{A Historical Perspective on CSR}

The debate for the need of 'social responsibility' surfaced with the boom of industrialization that impacted the social and environmental balance by way of policies and activities linked to the business operations. The emerging moral market-place factor and increasing conscience-focused customer demanded businesses to take publically known steps for the safeguard of community and conservation of environment. To encourage organizations improve upon their corporate disclosure practices, a shift from antagonistic activism to positive engagement between organizations and their stakeholders was witnessed. However, until the 1980s, CSR was considered same as corporate philanthropy (Waheed, 2005).

The modern CSR concept started to take shape in the 1980s when Bhopal disaster in India (1984), Chernobyl disaster in Ukrain (1986), Exxon Valdez oil spill in Alaska (1989) and consumer boycott of Nike sweatshirts (1996), among other notable happenings, created the realization that organizations should take publically known accountable measures through their business activities and community development programs (MacDonald, 2006). In this connection, United Nations furnished Sullivan Principles in 1977. Later, World Business Council for Sustainable Development (WBCSD) was formed in the 1990s that led to the introduction of social auditing by third party. Soon Social Accountability International, Forest Stewardship Council and a host of others joined hands to form the International Social and Environmental Accreditation and Labeling (ISEAL) group to oversee standard implementation. By the 1990s, SA8000, ISO14000 and Global Reporting Initiative's Sustainability Reporting Guidelines (GRI) were introduced (Waheed, 2005). Of late, World Trade Organization (WTO) helped organizations to demonstrate responsible behavior towards its stakeholders.

The evolution of CSR can be divided into three phases. The First Wave that was pressure driven by society and government and focused on philanthropy and legal compliance. The Second Wave that is efficiency-centered and market focused. And the Third Wave, where corporations are now moving towards responsible competitiveness which is differentiation through innovation, sustainability and future focus (Waheed, 2005). It could be safely assumed that most of the organizations in Europe and North America are riding the third wave; in Asia Pacific most of the companies belong to the second wave; while in Pakistan, where the CSR journey has lately started, business entities are struggling with the first wave.

\subsection{The Business case for CSR}

The proponents of CSR argue that it helps businesses to go beyond their own shortterm profits. Critics on the other hand argue that CSR only serves as window-dressing and does nothing but to distract business from playing its fundamental economic role. 
However, time has proved that all leading companies across the globe place considerable importance of adapting to CSR (Waheed, 2005). IBM global CEO study (IBM, 2008) highlighted that out of the nine change drivers, CEOs selected environmental issues, socio-economic factors and selected people skills as three top change drivers needed for future enterprise and all three are linked to CSR. Committee Encouraging Corporate Philanthropy (CECP) Board of Boards Report (Board of Boards CEO Conference, 2008) mentioned that $100 \%$ CEOs believe that corporate philanthropy is important to creating long-term shareholder value. Another study conducted by CECP (Committee Encouraging Corporate Philanthropy, 2008) revealed that despite the mixed economic climate, the median of corporate giving climbed from USD 24.6 million to USD 26.05 million, making a totaled contribution of over USD 11.6 billion. Furthermore, the 2002 Cone Corporate Citizenship Study (Kotler, 2005) reported that $84 \%$ of Americans would likely to switch to brands that are associated with a good cause, if price and quality are similar.

The triple bottom line approach emphasize that 'profits' are as essential to any CSR intervention as the development of the cause itself. A case in point is the introduction of lodized salt in Pakistan in 1993. In collaboration with the government of Pakistan, United Nations Children's' Fund (UNICEF), Population Services International, and the Canadian International Development Agency (CIDA), the Pakistan lodized Salt Project was launched. The project worked with the salt industry to ensure a sustainable supply of lodized salt while simultaneously creating a demand among consumers. The project created nearly 35 million new users of lodized salt, impacting the bottom line of the salt producing companies while improving upon the health of the communities.

CSR improves corporate clout, provides a moral edge that brings goodwill, increased ability to attract and retain employees and improved sales. CSR transmits greater value especially to the local companies as it helps them to expand overseas or to attract foreign investments. One of the favorable factors that made TATA India preferable on its competitors in bidding for Jaugar Land-Rover was their repute to carry out successful CSR interventions (Radia, 2008)

Many organizations are intelligently using CSR in the current financial turmoil. Rather than slashing on CSR budgets and sending a message that CSR is only spare money for the "good times" only, they are maintaining their CSR activities. In return they are obtaining the increased trust of the customer and the market share of those who have taken a back seat (Welford, 2009).

\subsection{CSR Scenario in Pakistan}

Traditionally, the Pakistani culture is depictive of genuine altruism. Having roots in individual philanthropy like Zakat, Sadqa and Khairaat (Religious obligations for charity in Islam ), philanthropy is an essential part of the moral fiber of society. A National Survey of Individual Giving 1998-99 reported in Indigenous Philanthropy Report 2000 estimated a total philanthropy of Rs. 70.5 billion (Ghausi, 2008). With such religious and cultural emphasis on individual giving, corporate philanthropy and then CSR came as a natural outcome. However, shifting from the mindset of individual-giving to a broader 
belief of CSR proved to be a challenge for the business practitioners.

Pakistan adapted to CSR initially on involuntary basis due to externally imposed regulatory pressures. Country's carpet, textile and sports industry lost billions of dollars due to reported child labor issues (Waheed, 2005). To sustain the business, exporting firms started to comply with trade requirements (Fariduddin, 2007). The first step to institutionalize CSR was the establishment of the Pakistan Centre for Philanthropy (PCP) in 2001. PCP introduced a Non-profit Organisations' (NPO) Certification Program which was an independent evaluation of the NPO. Upon meeting the certification standards, the NPO is awarded a 'seal of good housekeeping' (Pakistan Center for Philanthropy, 2006). This certification program helped individual and corporate donors in identifying credible partners for social development and also formed the basis for NPOs to claim tax benefits from the Federal Board of Revenue (FBR). PCP also launched Pakistan Corporate Philanthropy Awards in 2007 for public listed companies. In September 2005, Securities and Exchange Commission of Pakistan (SECP) conducted an exhaustive research that evaluated the state of CSR in Pakistan (Waheed, 2005). SECP also included CSR as part of legislation when it introduced the Code of Corporate Governance. The year 2002 Trade Policy articulated the government's objective to adhere to international industry benchmarks. In 2003, Pakistan Compliance Initiative was formed with support of international buyers, the textile sector and the Ministry of Commerce. A draft national standard was developed to replace many international social and environment compliance standards and buyers code of conduct. This resulted in inclusion of social compliance in the trade policy and initiation of a project proposal by Ministry of Science and Technology to European Union (EU) for encouraging SA8000 implementation (Waheed, 2005). Additionally, a CSR committee was formed by Federation of Pakistan Chambers of Commerce and Industry (FPCCI) in April 2008 (Ghausi, 2008). FPCCI later introduced annual CSR awards. Furthermore, Association of Chartered Certified Accountants (ACCA) and World Wide Fund (WWF) in May 2002 jointly introduced annual environmental reporting awards. Helpline Trust initiated CSR awards in 2007 to encourage organizations towards CSR activities. The first magazine on CSR 'Triple Bottom Line' (TBL) was introduced in January 2008.

CSR was brought to Pakistan mainly by the multinational companies who were later allowed to go 'glocal' by their foreign parent head offices by defining their local CSR strategies under the broad central policy (Fariduddin, 2007). A few Pakistani organizations followed into their footsteps and developed CSR functions as an 'additional' responsibility to either Human Resources, Corporate Communication or to Public Affairs department. Fariduddin (2007) mentioned four types of CSR strategies prevalent in Pakistan at present. These are 'politically motivated CSR strategies' that are aligned with the current political slogan and are conducted to gain political mileage; 'globally aligned CSR strategies' that are generally practiced by multinational companies; 'externally imposed CSR' where organizations do CSR activities for legal/regulatory compliance and trade requirements; and 'philanthropic and responsive CSR' that revolves around general principle of 'doing good' towards a defined social service need.

CSR in Pakistan generally contributes towards 'sweet causes'; like healthcare, education, 
water and food provision, disaster relief, environment conservation, and infrastructure development. A survey of $\mathrm{OICCI}$ member companies (Overseas Investors' Chamber of Commerce and Industry, 2009) revealed that $90.2 \%$ organizations have focused on education; $88.2 \%$ on community development and $78.4 \%$ on health related causes, making them the top choices for CSR activities. With due acknowledgment to Jas Ahmed of Middlesex University Business School, who published a comprehensive survey on CSR practices in Pakistan in May 2006 mentioned that most of the CSR spending is directed towards healthcare, education and social welfare, and relatively less attention is being paid to responsibilities towards customers. The study also revealed the higher percentage of respondents as $69 \%$ and $94 \%$ respectively in making regular and occasional financial contributions that further strengthens the stance that Pakistani companies are inclined towards corporate philanthropy. Ghausi (2008) approved this approach by mentioning that corporate philanthropy has increased to almost ten times from Rs. 228 million in the year 2000 to Rs. 2.3 billion in 2006.

Many business leaders still see CSR more as a self-actualized act than as socially responsible attitude. To many, CSR is either compliance to the regulatory requirements or simply a popularity contest. Many others treat CSR as a stand alone function that does not form part of the overall business cycle. To ensure the success of CSR funding, many organizations have set up their own foundations and trusts. Jang Group of publications established Mir Khalilur Rehman (MKR) foundation, Abbott formed Abbott Fund and ICl established ICI Pakistan Foundation.

Although a wealth of annual CSR reports are being produced in Pakistan, a lot of organizations still remain reluctant to publically share their CSR doings. Therefore, many worthy CSR initiatives remain inadequately documented, failing to aptly reflect the contributions made or providing inspiration to other corporate entities. On the other hand, many organizations are publishing their CSR reports and can be found following the Global Reporting Initiative (GRI) guidelines. An OICCI led survey (Overseas Investors' Chamber of Commerce and Industry, 2009) showed that 8 companies are signatory to the principles of UN Global Compact. Unfortunately no nationally recognized CSR benchmark is available for the compliance nor is any incentive policy in place that can benefit the CSR complaint organizations (Waheed, 2005).

To create awareness on CSR, a host of privately owned organizations and consulting firms have started organizing conferences, workshops and training programs. The World Conservation Union, Pakistan (IUCNP) in January 2006 organized an IUCNP-PELG's chairpersons/CEOs roundtable on value of CSR to Pakistan's business sector. The Aga Khan Foundation (Pakistan) organized workshops on CSR. The NGO Resource Center (NGORC) supported dissemination of education on CSR by publishing a special issue of its NGORC journal in June 2007. United Nations Industrial Development organization (UNIDO), Responsible Business Initiative (RBI), Global Compact Foundation Pakistan (GCF) and Pakistan Compliance Initiative (PCI) among others also participated in creating awareness and development of CSR (Waheed, 2005). Leading educational institutions have started offering courses on CSR in their MBA programs to enable their graduates remain at the learning curve. To create branding, leading organizations have 
started promoting their CSR doings through media advertisements that have further promulgated the CSR awareness. Many have added a separate CSR page on their websites. However, with all the CSR related development that is taking place, Pakistan's business entities are yet to fully understand the business case of CSR and the differential advantage it brings.

\subsection{The Issue of Credible CSR Partnerships}

The buzz word 'sustainability' has been matured into a broader sense to developing 'sustainable relationships'. It means weaving threads between the organizations, the community, the project, stakeholders and utilizing shared resources to build partnerships of solid worth to meet CSR targets, for now and for future (Waheed, 2005). The partnership ensures engaging the beneficiaries in planning, implementation and monitoring that is a key to any successful community development project (Pakistan Center for Philanthropy, 2006). Globally, organizations pursuing CSR have entered into meaningful CSR partnerships that have presented favorable results. Subway partners with American Heart Association to create awareness on healthy hearts; Pampers partnering with National Institute of Child health and Human development to prevent Sudden Infant Death Syndrome (SIDS) that led to the decrease in SIDS rate in United States by more than 50\% since their campaign began in 1994; and Mustang Survival partner up with Washington state's children Hospital in a drowning prevention campaign. After first year of campaign, Mustang reported $25 \%$ increase in sales from the prior season (Kotler, 2005).

Businesses in Pakistan have also entered CSR partnerships. The primary sources and review of available annual company reports on CSR indicated that an estimated 160 CSR partnerships are known to exist in Karachi. For instance; Procter \& Gamble and Edhi Foundation for children welfare; ICl and LRBT to hold free eye clinics; Unilever with TCF for children education' Engro Foods and Nestle joining hands with UNDP and CELDAC to support livestock development in rural areas, Pakistan Tobacco Company with Community Citizen Boards and District Government to install water filtration plants and Getz Pharma working with the Bookgroup and Zindagi Trust towards women education (Ishaque, 2008). However, barring a new notable exceptions, it is important to mention that many CSR alliances have either come accidently to the partners without doing much of the conscious effort or have been an outcome of the convenience of the particular situation (Shariff, 2009). While the foremost aspirations for the corporate entities seem to be brand promotion and goodwill, customer loyalty, differentiation from competition, employee motivation and retention, higher sales and philanthropy for community development, the charitable institutions yearn for new funds for their organizational sustainability, publicity and strategic alliances with new clients and supporters. To form a mutually beneficial relationship, it is imperative that both the partners perform conscious efforts to understand each others' motivations. The NonProfit Organizations (NPO) certification program by the Pakistan Center for Philanthropy (Pakistan Center for Philanthropy 2006) has helped to making a credible CSR partnership by certifying the transparency of the partner NGOs. 
With the increasing needs for CSR partnerships, investigations are required to find out the causes of inhibition of credible CSR partnerships. Ironically, no explicit statements are available that indicate the key factors in forging credible CSR partnerships. Empirical research on CSR and related partnership issues doesn't exist in Pakistan at present. However, literature review implies certain key issues that have been explored further in this study. The following research will bring to light the key issues and factors those inhibit the corporate and development sector form a reliable CSR partnership while suggesting ways to uphold the relationship in a manner that guarantee an optimal level and sustainable CSR intervention.

\section{Research Findings}

Two different types of questionnaires, having similar approach, were circulated to 60 corporate and development sector organizations in Karachi using convenient sampling method. Respondents were head of public affairs and corporate communication functions, CSR representatives in the corporate sector and heads of NGOs in addition to sustainability consultants who are involved in CSR operations and partnerships. The total response spread is from 34 organizations that comprise 53\% (18 in numbers) for-profit and 47\% (16 in numbers) not-for-profit organizations in Karachi. Liner regression test has also been applied to rank order the key issues that inhibit credible CSR partnerships. Since an estimated 160 CSR partnerships are known to exist in Karachi, the results from linear regression can be extrapolated to form judgment about the universe. For the purpose of simplicity and understanding, bar graphs have been chosen for graphical representation of the research findings in the following manner:

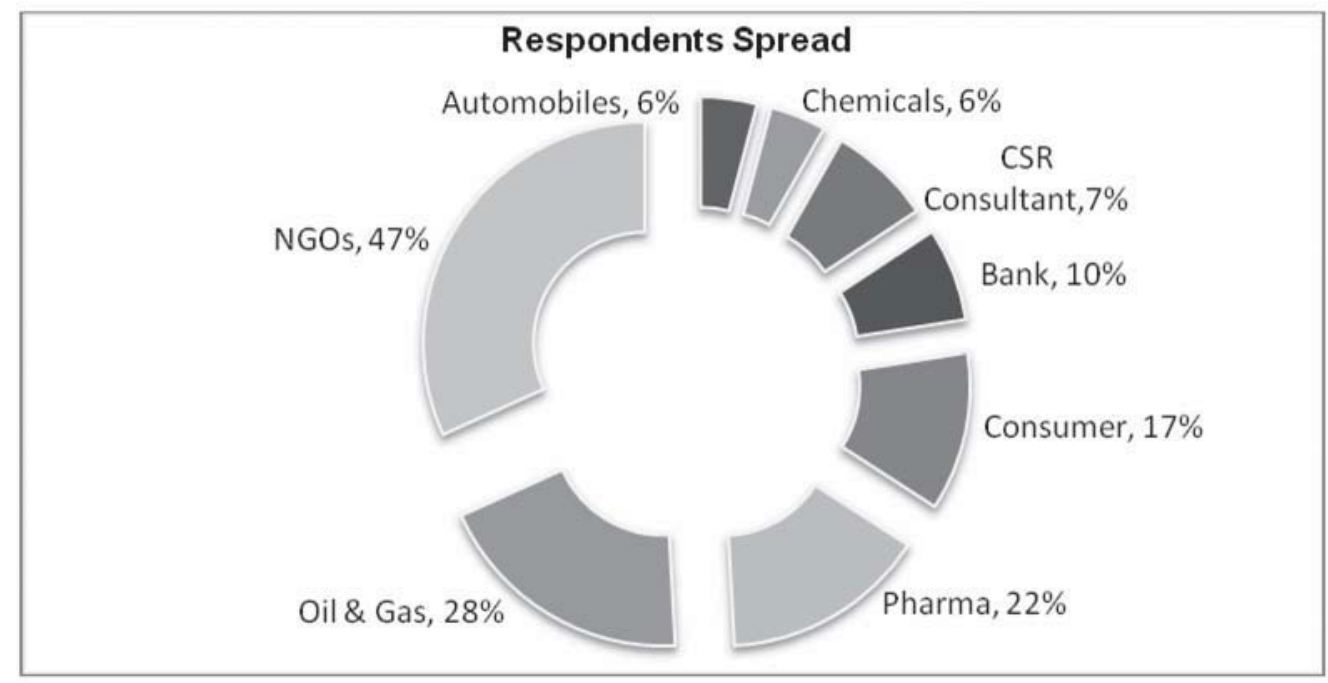

Research question-1: To find out the types of CSR interventions corporate organizations and NGOs remain involved into more, the research question-1 presents an interesting picture: 


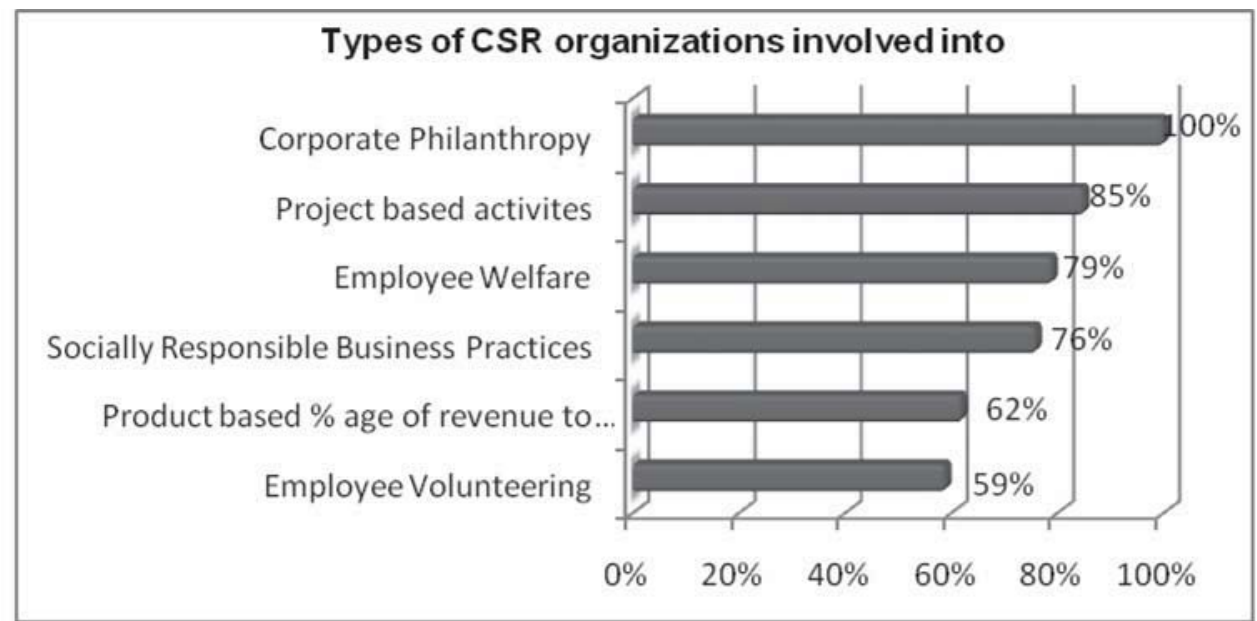

The highest rating of corporate philanthropy $(100 \%)$ by organizations in the research findings matches up with the corporate philanthropy inclination mentioned in the literature review. Project-based CSR activities (85\%) reveals increasing trend towards having outcome-based CSR activities. A heartening find is the organizations' focus on internal CSR that relates to employee welfare $(79 \%)$.

In search of finding that whether organizations are inclined only towards the popular CSR causes or are willing to consider controversial yet worthy causes, five (5) such causes were explored in the questionnaire and following are the results:

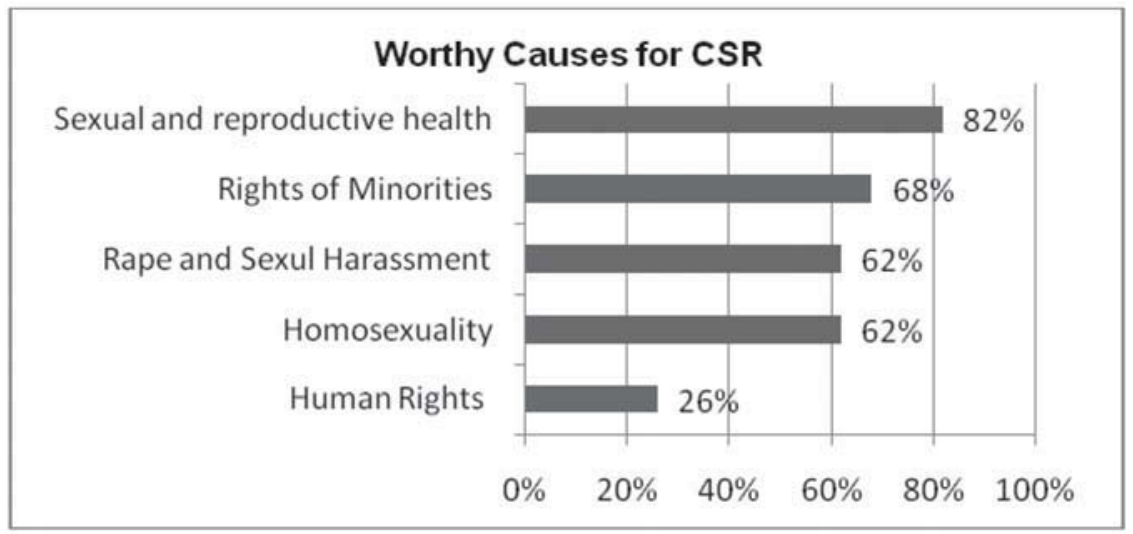

With few exceptions, corporate and development organizations unanimously showed their motivation to support the controversial causes. However, they were of the opinion that CSR for these causes may be initiated through a forum where resources are pooled to achieve greater benefits.

Research question-2: In response to the preferred areas to conduct CSR activities, 
organizations respond in the following manner:

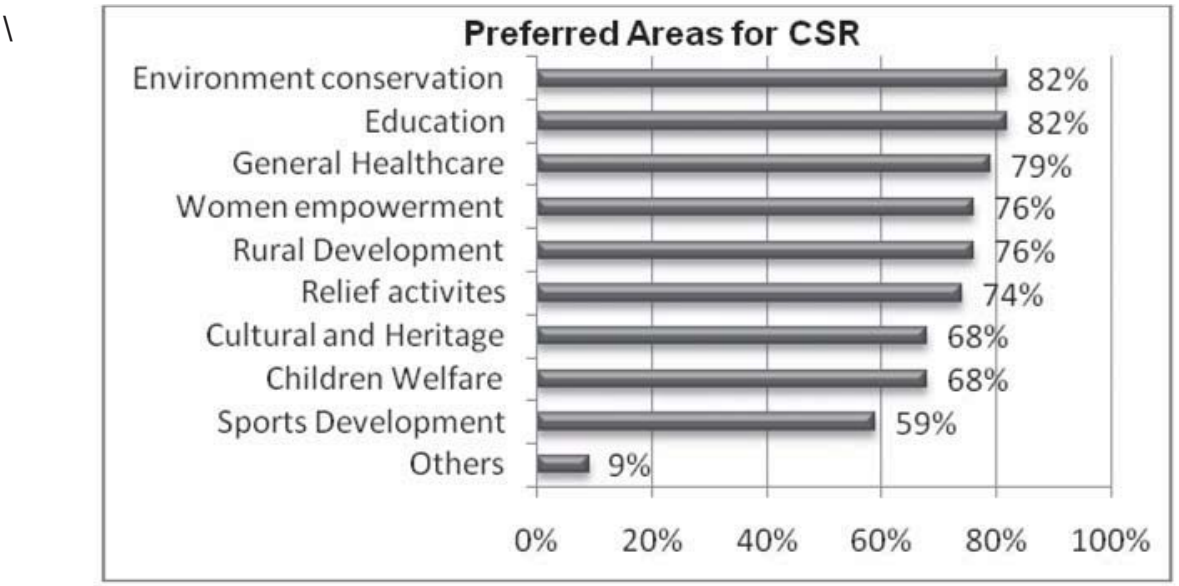

An equal focus on environment conservation ( $82 \%)$, education ( $82 \%)$ followed by general healthcare (79\%), women empowerment and rural development $(76 \%)$ each signifies the importance of these areas for CSR, especially in Pakistan where the government fails to improve upon their state of affairs. A positive focus on support of culture and heritage (68\%) through CSR activities presents a healthy orientation of the local CSR approach.

Research question-3: Mentioning the motivations and driving factors to get into CSR activities, corporate sector mentions the following:

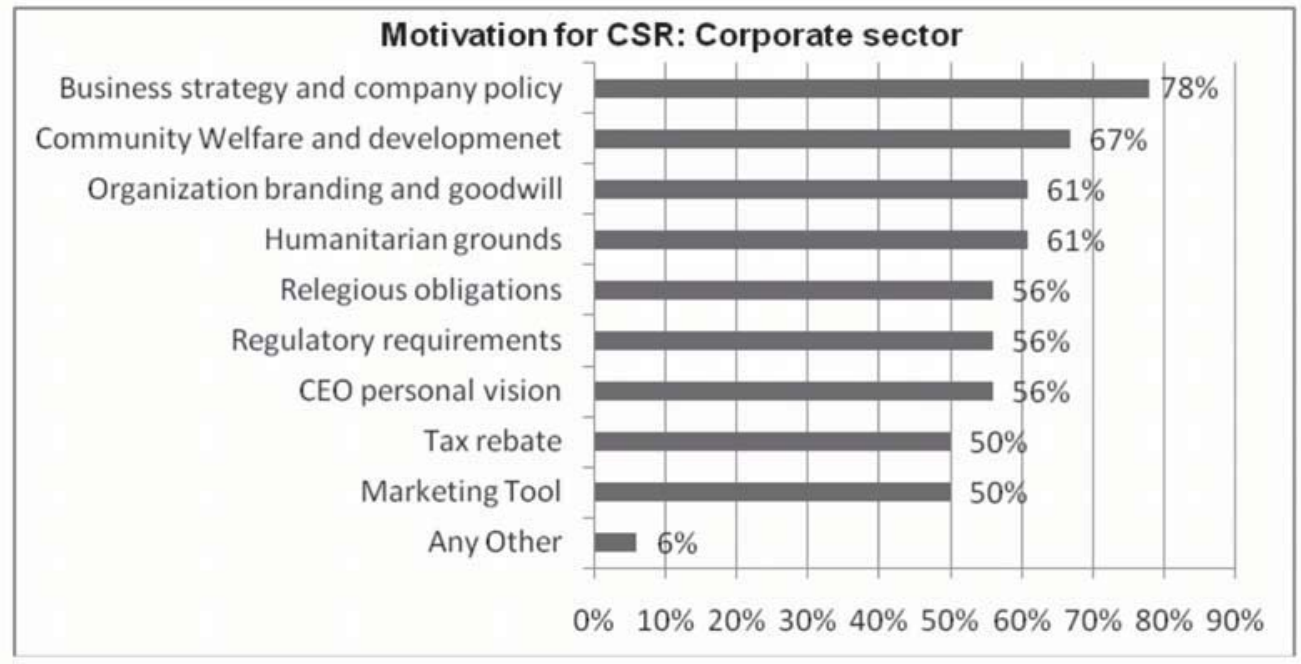

The development sector has a different set of motivations to get into CSR activities which are: 


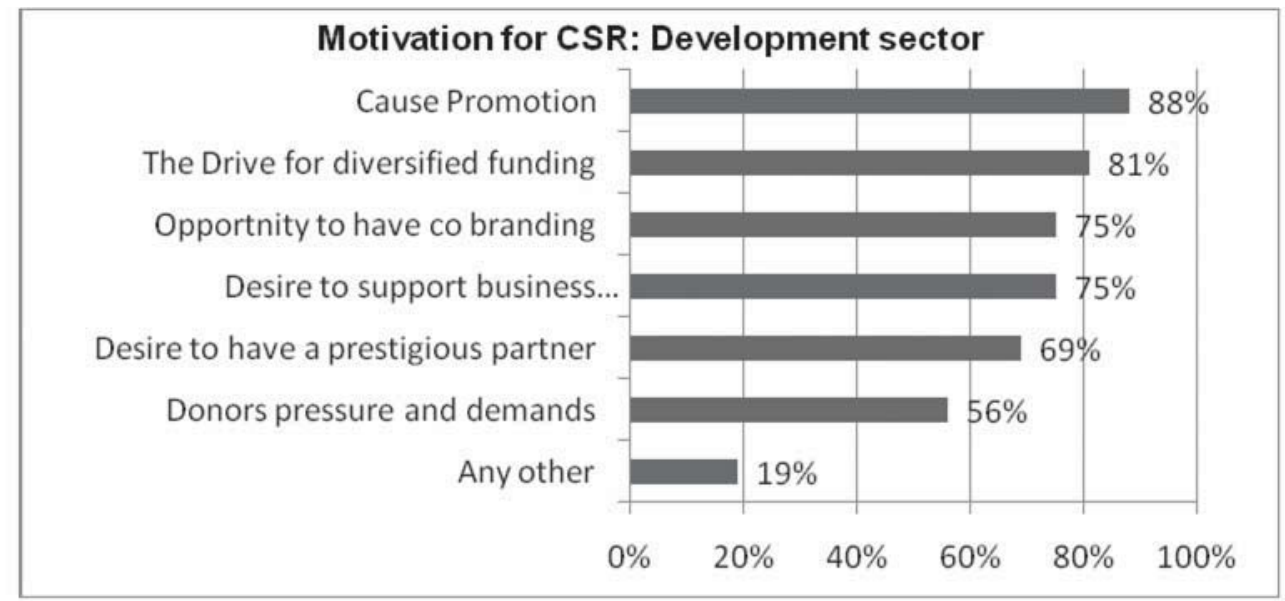

Business strategy and company policy $(78 \%)$, community welfare $(67 \%)$, company goodwill $(61 \%)$ for the corporate sector and cause promotion $(88 \%)$, drive for diversified funding $(81 \%)$ and opportunity for co-branding $(75 \%)$ came out as top motivations and drivers to get into CSR activities. Dissimilarity is evident in the motivational factors between the corporate and development organizations.

Research question-4: Responding to the core question of key partnership issues, the collective response of the corporate and development sector came out as follows:

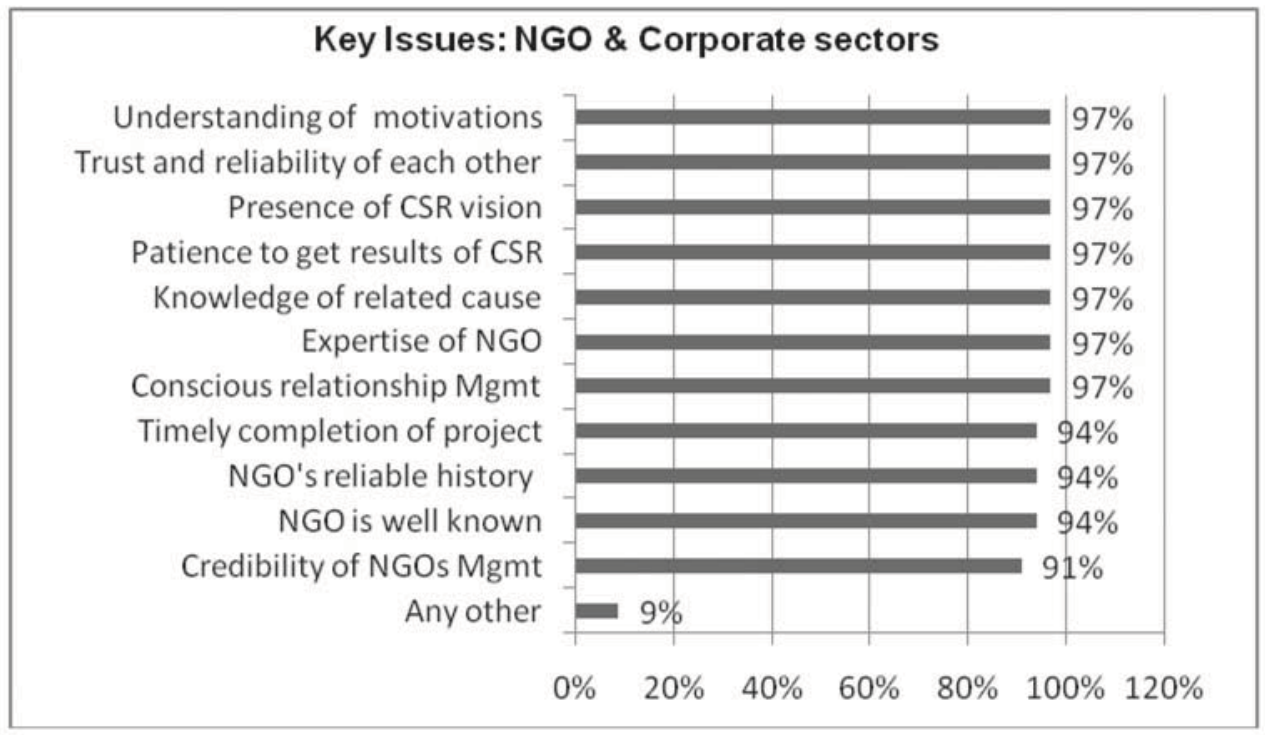

It can be observed that top 7 key issues are marked as equally important. To find out the real and key issues in forging credible CSR partnerships and to rank order them, simple liner regression test is applied. 


\section{Liner Regression Test for key issues significance and hypothesis testing using MS Excel:}

To find out the significant key issues, cut off weightage of responses (dependent variable) was determined as follows:

Total responses (low+medium+high) of an individual respondent $=14$ $80 \%$ of 14 was determined as a cutoff significance of the dependent variable. $95 \%$ was kept as the cut off margin for the independent variables (the key issues) so that only the most significant issues crossing the $95 \%$ benchmark qualifies to be the key issues. Hence, the probability value was $P=0.05$. Key issues that remained less than the defined $P$-value were declared significant.

Following regression equation is used to test the significance of key issues:

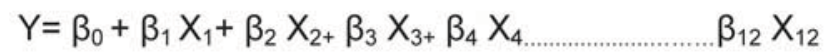

Following results were achieved after running the Line Regression method:

Table-1

"Summary Output of the Regression Analysis"

\begin{tabular}{|c|c|c|c|c|}
\hline No & Key Issue & $\begin{array}{l}\text { Percentage in } \\
\text { Survey }\end{array}$ & P-value $<0.05$ & Remarks \\
\hline 1 & $\begin{array}{l}\text { Conscious relationship } \\
\text { Management }\end{array}$ & $97 \%$ & 0.396 & Rejected \\
\hline 2 & Credibility of NGO's Mgmt & $91 \%$ & 0.003 & Accepted \\
\hline 3 & Expertise of NGO & $97 \%$ & Not significant & Rejected \\
\hline 4 & Knowledge of related cause & $97 \%$ & Not significant & Rejected \\
\hline 5 & NGO is well known & $94 \%$ & 0.002 & Accepted \\
\hline 6 & NGO's reliable history & $94 \%$ & 0.002 & Accepted \\
\hline 7 & Patience to get results of CSR & $97 \%$ & 0.766 & Rejected \\
\hline 8 & $\begin{array}{l}\text { Presence of CSR vision in } \\
\text { partners }\end{array}$ & $97 \%$ & 0.009 & Accepted \\
\hline 9 & Timely completion of project & $94 \%$ & 0.698 & Rejected \\
\hline 10 & Trust and reliability of each other & $97 \%$ & Not significant & Rejected \\
\hline 11 & Understanding of motivations & $97 \%$ & Not significant & Rejected \\
\hline
\end{tabular}

Using the liner regression, the following assumed null hypothesis was also tested:

$\mathrm{H}_{0}$ - Lack of understanding about each other's motivations and intentions does inhibit formation of credible CSR partnerships.

$\mathrm{H}_{1}$ - Lack of understanding about each other's motivations and intentions does not inhibit formation of credible CSR partnerships.

By running ANOVA test, following results were achieved: 
Table-2

"Summary Output of the ANOVA Test"

\begin{tabular}{|ccc|}
\hline Regression & Df & p-value \\
& 12 & $3.0494 \mathrm{E}-05$ \\
\hline
\end{tabular}

The P-value of the overall regression model came out to be $3.05 \mathrm{E}-05$ (or 0.0000304940178857493 to be exact) which is less than 0.1 which was set as the significance criteria.

Hence based on the result, the $\mathrm{H} 1$ is rejected and it is established that lack of understanding about each other's motivations and intentions does inhibit formation of credible CSR partnerships. The four statistically valid issues that most contribute to this lack of understanding are found to be Credibility of NGO's management; NGO is well known; NGOs reliable history of performance and Presence of CSR vision in partners.

Four variables were rejected on the basis of abnormally high T-stats value.

Research question-5: Both the corporate and development sector were asked to mention two key attributes of their current best CSR partner. The top collective responses were: Demonstrated reliability, transparency, and timely completion of CSR ventures; documented roadmap for the support of cause and accountability procedure; innovative professional management with understanding of the cause and credibility of the organization's management/CEO.

It is interesting to observe that the opposite of mentioned key attributes are the identified key issues in forging CSR partnerships. It indicates that the absence of key attributes will make them key hurdles in partnership formation.

\section{Conclusion and Recommendations}

The study concludes that the lack of understanding about each other's motivations and intentions does inhibit formation of credible CSR partnerships between the corporate and development sector organizations and the four statistically valid issues that most contribute to this lack of understanding are found to be Credibility of NGO's management; NGO is well known; NGO having reliable history of performance and Presence of CSR vision in partners.

It is also concluded that two different sets of motivations exist for corporate and development sectors. Corporate sector mentioned business strategy and company policy, community welfare, company goodwill and cause promotion as their motivations while drive for diversified funding, desire to having a prestigious partner and opportunity for co-branding from development organizations came out as important factors to NGOs. To gap these dissimilarities, it is recommended that both the partners should put purposeful efforts to go extra mile in exploring each others' motivations to jointly conduct CSR sustainable activities. 
The study also highlighted key attributes of the current CSR partners like; demonstrated reliability, transparency, and timely completion of CSR ventures; progressiveness, quality orientation, innovation and dedication to cause; professional management; and credibility of the organization's management among others. It is interesting to note that the identified key attributes by the responding organizations map with the identified key issues of credible CSR partnerships. By juxtaposing both findings, it becomes clear that the mentioned key attributes, if not present in the partner, get transformed into key issues. These findings also hint that the current CSR partners exist only because both partners are able to find the mentioned key attributes in each other. Since sustainable and consciously developed CSR partnerships are not a very widespread practice in Pakistan, it can be safely concluded that the identified key attributes are not commonly found or explored, hence key issues are prevalent that inhibit the CSR partnerships.

The study also authenticates findings mentioned in the literature review relating to the CSR causes being supported in Pakistan. Corporate philanthropy among all CSR initiatives tops the list followed by project-based CSR. A heartening find is the organizations' focus on internal CSR that relates to employee welfare which is an indication of employees being considered as an important part of the overall CSR sphere. Another useful finding is the unanimous response and willingness to go beyond the 'sweet causes' like healthcare, education and environment conservation to controversial by worthy causes like sexual and reproductive health, rights of minorities and alike. The positive response to these issues highlight that the organizations and NGOs have started to look ahead towards more intense and contentious CSR causes so that they can play a broader role for the community uplift. However, they would like to move towards this goal in a slow but steady and sure manner by pooling-in their resources, finances and energies and by getting into purposeful multiple partnerships to achieve larger scale of rewards for themselves, their stake holders and the community.

Looking at the current trends, it can also be safely concluded that Business-NGO partnerships will increase at both the bilateral and multilateral levels. Keeping in view the uptight economic conditions, it is only a matter of time that business to business partnerships will also surface where the organizations will pool their resources and cobrand to achieve a larger scale of economies for their common stakeholders and communities.

Following areas for further research are recommended:

1. The undertaken research of key issues in forging credible CSR partnerships could be extended at country level by taking in account other entities of CSR partnerships.

2. Exploration of CSR partnerships in multi-actor and multi-sector environments as this study has focused on bilateral CSR partnerships

3. The available and required legal framework for public-private partnerships. 


\section{References}

Anwar, Farhan (2007), 'Corporate Social Responsibility: Profiting with Conscience', NGORC Journal, June, Pakistan, NGO Resource Center, Vol. 8, No. 1, pp.15-18.

Board of Boards CEO Conference (2008), The CEO's Challenge: Leading the company, shaping society, www.corporatephilanthropy.org/research/pubs /CECPBoardofBoards2008.pdf.

Committee Encouraging Corporate Philanthropy (2008), Giving in Numbers, www.corporatephilanthropy.org

Fariduddin, Shadab (2007), 'Corporate Social Responsibility: Trends and Types in Pakistan', NGORC Journal, June, Pakistan, NGO Resource Center, Vol. 8, No. 1, pp. 4-7.

Fariduddin, Shadab (2008), 'CSR for CSR', TBL- CSR Journal, (May-June), Pakistan Asiatic Public Relations Network, No. 3, pp. 42-43.

Federation of Pakistan Chambers of Commerce and Industry (2009), www.fpcci.com.pk/about-csr.asp

Ghausi, Sabihuddin (2008), 'Social Responsibility: A Business Discipline', Daily Dawn, December 22, Pakistan, Herald Publication.

Ishaque, Fouzia, (2008), 'The Hunger Opportunity', TBL- CSR Journal, May-June, Pakistan, Asiatic Public Relations Network, No. 3, pp. 14-16.

IBM, (2008), IBM global CEO study: The enterprise of the future, http://ibm.com/enterpriseofthefuture

Kotler, Philip and Nancy Lee (2005), Corporate Social Responsibility, New Jersey, John Wiley \& Sons.

MacDonald, Bruce, (2006), The Changing Face of Corporate Responsibility, www.sharealittlemagic.ca/rapport/archives/english/2006-2.pdf,

Overseas Investors' Chamber of Commerce and Industry (2009), A report on the corporate \& social responsibility initiatives and activities of $\mathrm{OICCI}$ member companies, OICCl, February, Pakistan, OICCI.

Pakistan Center for Philanthropy (2006), Going beyond Business, www.pcp.org.pk/pdf/Research/going $\% 20$ beyond $\% 20$ business.pdf

Radia, Niira (2008), 'CSR beyond Telling', Business World, 26 May, New Delhi, India, 
Vol. 28, No. 1, p. 46.

Shariff, Zohare Ali (2009), 'The future of Corporate Social Responsibility,' TBL- a specialized CSR Journal, Jan-Feb, Pakistan, Asiatic Public Relations Network, No. 7, pp. 12-16.

Waheed, Ambreen (2005), Evaluation of the state of Corporate Social Responsibility in Pakistan and a strategy for implementation,

www.secp.gov.pk/Reports/CSR_Study_FinalReport_November.pdf

Welford, Richard, (2009), How can corporations respond to CSR in a recession? CSR360 Global partner Network, (2009), www.csr360gpn.org/magazine/feature/how-cancorporations-respond-to-csr-in-a-recession/ 